\title{
Two cases of pseudohermaphroditism in loggerhead sea turtles Caretta caretta
}

\author{
Jose Luis Crespo ${ }^{1,2, *}$, Daniel García-Párraga ${ }^{1}$, Ignacio Giménez ${ }^{3}$, \\ Consuelo Rubio-Guerri², Mar Melero², José Manuel Sánchez-Vizcaíno², \\ Adolfo Marco ${ }^{5}$, Jose A. Cuesta ${ }^{6}$, María Jesús Muñoz ${ }^{4}$ \\ ${ }^{1}$ Veterinary Services, Oceanogràfic, Ciudad de las Artes y las Ciencias, C/ Eduardo Primo Yúfera (Científic), 46013 Valencia, \\ Spain \\ ${ }^{2}$ VISAVET Center and Animal Health Department, Veterinary School, Complutense University of Madrid, \\ Avda. Puerta del Hierro, 28040 Madrid, Spain \\ ${ }^{3}$ Rara Avis Biotec, C/ Moratin 17, 46002 Valencia, Spain \\ ${ }^{4}$ Animal Health Research Center, CISA-INIA, Ctra. de Algete a El Casar s/n, 28130 Valdeolmos, Madrid, Spain \\ ${ }^{5}$ Estación Biológica de Doñana (CSIC), C. Américo Vespucio s/n, 41092, Sevilla, Spain \\ ${ }^{6}$ Instituto de Ciencias Marinas de Andalucia (CSIC), Avda. República Saharaui, 2, 11519 Puerto Real, Cadiz, Spain
}

\begin{abstract}
Two juvenile (curved carapace lengths: 28 and $30 \mathrm{~cm}$ ) loggerhead sea turtles Caretta caretta with precocious male external characteristics were admitted to the ARCA del Mar rescue area at the Oceanogràfic Aquarium in Valencia, Spain, in 2009 and 2010. Routine internal laparoscopic examination and subsequent histopathology confirmed the presence of apparently healthy internal female gonads in both animals. Extensive tissue biopsy and hormone induction assays were consistent with female sex. To the best of our knowledge, this is the first report of pseudohermaphroditism in loggerhead sea turtles based on sexual external characteristics and internal laparoscopic examination. Our findings suggest that the practice of using external phenotypical characteristics as the basis for gender identification in sea turtles should be reevaluated. Future research should focus on detecting more animals with sexual defects and their possible effects on the sea turtle population.
\end{abstract}

KEY WORDS: Sex development disorder - Loggerhead turtle - Caretta caretta · Reptile · Endocrine disruptor

\section{INTRODUCTION}

Early sex identification is a constant challenge in sea turtles given the invasiveness of actual procedures and their importance in sex ratio estimation, which is considered an indispensable tool to evaluate and manage animal populations, especially in wildlife programs. Slight temperature fluctuations can significantly affect the sex ratio of populations of certain species, including sea turtles (Warner \& Shine 2011, Patiño-Martínez et al. 2012). Therefore, this parameter is important for monitoring the dynamics of captive and free-ranging populations (Raynaud \& Pieau 1985, Janzen \& Paukstis 1991). Sea turtles display temperature-dependent sex determination (TSD; Yntema \& Mrosovsky 1982, Standora \& Spotila 1985, Crews et al. 1994): their sexual phenotype is determined during the thermosensitive period of egg incubation (Miller \& Limpus 1981, 2003, Pieau et al. 1994). Temperature fluctuations affecting the sex ratio can arise due to natural (e.g. beach thermal zones, meteorological 
conditions) and anthropogenic changes, such as global warming, but also by the artificial manipulation of incubation temperatures in controlled ex situ breeding programs. The pivotal temperature is defined as that at which offspring sex ratio comes close to $1: 1$. Incubation near the pivotal temperature is the most widely accepted explanation for intersex turtles which, in morphological terms, are neither male nor female (Limpus et al. 2009). Studies of gonadal intersexuality in chelonians have described the presence of ovotestes (Ewert et al. 1994, Mrosovsky \& Godfrey 1995, Wibbels \& Crews 1995). In addition to obvious or prominent immature seminiferous tubules, these individuals have a thick or thin cortex with female characteristics (Whitmore \& Dutton 1985). Apart from in ovo or neonate individuals, at least 1 adult sea turtle has been reported with apparently healthy, independent male and female gonads, and has also been classified as intersex (Limpus et al. 2009).

Three sea turtle species inhabit the Mediterranean Sea: the green sea turtle Chelonia mydas, the leatherback sea turtle Dermochelys coriacea, and the loggerhead sea turtle Caretta caretta, with loggerheads being the most abundant (Broderick et al. 2002). For loggerheads, the Valencian community in the western Mediterranean is an important mixed foraging ground of juveniles which come from nesting areas in the western and eastern Atlantic and the eastern Mediterranean (Laurent et al. 1993, Casale et al. 2002, Monzón-Argüello et al. 2010, Carreras et al. 2011). The rehabilitation area of the Oceanografic of the Ciudad de las Artes y las Ciencias (CAC) performs health status monitoring and rehabilitation programs with sea turtles and cetaceans stranded alive or by-caught in the Valencian region.

Reliable sex ratio estimates require accurate sex identification of individual animals. The sex of adult sea turtles is usually identified based on the sexual dimorphism of external features. The main secondary sexual characteristics are claw size, total tail length, and the distance between the caudal part of the plastron and the cloacal opening. In addition, as male turtles reach adult size, they tend to secrete more testosterone, which induces tail lengthening and penis development (Lutz et al. 2003). Adult females typically differ from males in that they have a shorter tail and their cloacal opening is located roughly halfway between the tip of the tail and the plastron's anal scute (Wyneken 2001). Technological improvements in endoscopy have enabled the identification of the sex of neonate and juvenile sea turtles by directly examining the gonads.
Intersex turtles have been observed in several places around the world. Limpus et al. (2009) reported an intersex green turtle Chelonia mydas on Raine Island (Australia) that was male externally, but female internally based upon laparoscopic examination. Some findings of mainly intersex hatchling sea turtles (Dutton et al. 1985, Mrosovsky \& Godfrey 1995) focused on histological examinations of gonads. However, no report of pseudohermaphroditism in sea turtles, based on external morphological features, endoscopic examination, gonadal biopsy, and hormonal testing, has been published.

Pollutants have been associated with a disruption of the endocrine function and possibly sex reversal in sea turtles and are therefore recognized as threats (Hamann et al. 2010). Environmental exposure to so-called 'endocrine-disrupting chemicals' (EDCs), which include industrial chemicals, pesticides, fungicides, plasticizers, and even phytoestrogens, can interfere with normal sexual development, especially when exposure occurs during certain critical periods. The US Environmental Protection Agency (EPA) defines endocrine disruptors as 'chemicals that either mimic or block the effects of hormones at the target receptor/tissue or by directly stimulating or inhibiting production of hormones by the endocrine system' (EPA 2007, p. 56342-56343). These compounds share the ability to derail natural hormonal systems and processes, although they may act by different mechanisms (Venerosi et al. 2012).

This report presents 2 cases of pseudohermaphroditism in loggerhead sea turtles based on external sexual characteristics and internal laparoscopic examination. We hypothesize that in addition to temperature fluctuation, there could be other causes, such as exposure to endocrine disruptors, which are able not only to disturb hormonal composition, but also to change turtle sexual characteristics.

\section{MATERIALS AND METHODS}

\section{Animals}

From 2006 to late 2012, 162 stranded sea turtles were admitted to the ARCA del Mar rescue area of the CAC (20 to 30 individuals annually) for rehabilitation and later release. In order to detect signs of illness, these individuals were externally examined and subjected to radiographic and ultrasound examinations. Since May 2011, laparoscopy, and gonadal biopsy sampling when necessary, have also been routinely performed to confirm gender and to detect 
internal pathologies (Limpus et al. 1994, Wyneken et al. 2007). Since that time, these 2 techniques have been used to identify the sex of 16 juvenile loggerhead sea turtles, including the 2 described in this report.

The maturity of turtles in the rescue area is estimated using several measurements (Wyneken 2001): straight-line carapace length (SCL), curved carapace length (CCL), straight-line carapace width (SCW), and curved carapace width (CCW).

\section{Sexing method}

As per standard procedure in this rescue area, the 2 animals analyzed in this report were fasted for $48 \mathrm{~h}$ prior to surgery. General anesthesia was carried out using a single intravenous injection of propofol (8 mg $\mathrm{kg}^{-1}$; Propofol-Lipuro ${ }^{\circledR} 10 \mathrm{mg} \mathrm{kg}{ }^{-1}$, B. Braun VetCare) as an inducing agent. Maintenance was accomplished by isoflurane (Isoba ${ }^{\circledR}$ vet ScheringPlough Animal Health) and oxygen (1-1.5\% at 0.9 l $\min ^{-1}$ ). Pain relief was administered using a single intramuscular injection of butorphanol tartrate (0.4 mg kg ${ }^{-1}$; Fort Dodge Veterinaria) and meloxicam (0.2 mg kg ${ }^{-1}$; Metacam ${ }^{\circledR} 5 \mathrm{mg} \mathrm{ml}^{-1}$, Boehringer Ingelheim Vetmedica). The local anesthetic lidocaine (Lidocaína 2\% Epinefrina Normon, Laboratorios Normon) was injected intradermally into the surgical access site in both prefemoral areas. Turtles received post-surgical antibiotic treatment with enrofloxacin (5 mg kg ${ }^{-1}$ every $48 \mathrm{~h}$; Baytril ${ }^{\circledR} 5 \%$, Bayer). The surgery site was prepared using povidone iodine (Betadine ${ }^{\circledR}$ Meda Pharma) and alcohol (Ethanol $96 \%$ cosmetic, Guinama).

To improve coelomic cavity visualization, insufflation through an access in the prefemoral fossa was carried out by an electronic $\mathrm{CO}_{2}$ insufflator (Endoflator ${ }^{\circledR}$, Karl Storz Veterinary Endoscopy Europe) and a pneumoperitoneum needle (Karl Storz). A $4.5 \mathrm{~mm}$ trocar (Karl Storz) was introduced into the incision, which was previously made in the contralateral fossa. Endoscopy was performed using a rigid endoscope with a $2.7 \mathrm{~mm}$ diameter and a $30^{\circ}$ angle; the endoscope was either housed directly inside the trocar or it was pulled out from the trocar and passed through the incision inside a cystoscopy sheath (Karl Storz). Instruments were cleaned and sterilized between procedures using a glutaraldehyde-based solution (Korsolex ${ }^{\circledR}$ plus, Bode Chemie) and were rinsed with sterile distilled water. Both gonads were identified by anatomical position, morphology, texture, and coloration (Hernandez-Divers et al. 2002, Kuchling
2006, Wyneken et al. 2007), and biopsies were taken for histological examination (Miller \& Limpus 2003).

Finally, the incision was closed using absorbable sutures (Monosyn ${ }^{\circledR}$ 2/0 Glyconate monofilament, Braun Aesculap VetCare). After surgery, the animals were kept warm in a dry environment for $24 \mathrm{~h}$ to ensure that the incision had closed and that the animals had recovered from anesthesia. This state was achieved $30 \mathrm{~min}$ after surgery when both animals presented palpebral and cloacal reflexes, regular breathing, and movement when touched.

\section{Histology}

The 2 gonads in both turtles were biopsied 3 times in different regions (cranial, medial, and caudal) to ensure that no testicular tissue remained within the ovaries. Biopsied tissue (1-2 $\mathrm{mm}$ in diameter) was preserved in $10 \%$ buffered formalin for fixation to prepare the histology sectioning. Paraffin sections were stained with hematoxylin and eosin (H\&E) for light microscopy purposes.

\section{Hormonal induction assay}

In order to evaluate gonadal response to the presence of ovarian or testicular tissue, turtles were bled before and after the intramuscular injection of recombinant avian follicle-stimulating hormone (FSH Rara1, Rara Avis Biotec) (Innis 1997). Animals were sampled at 48, 72, 96, and $144 \mathrm{~h}$ after the FSH injection. All samples were collected in lithium heparin tubes, and plasma was separated and frozen at $-30^{\circ} \mathrm{C}$ until analyzed.

\section{DNA extraction, amplification, and sequencing}

The DNeasy Blood and Tissue Kit (Qiagen) was used for DNA extraction from the tissue samples of the 2 specimens preserved in ethanol (96\%). A fragment of mitochondrial DNA, encompassing tRNAThr, tRNAPro, and the control region genes, was amplified by polymerase chain reaction (PCR) using primers LCM15382 (5'-GCT TAA CCC TAA AGC ATT GG-3') and H950 (5’-GTC TCG GAT TTA GGG GTT TG-3') (Abreu-Grobois et al. 2006). PCRs were conducted in $25 \mu \mathrm{l}$ volume reactions containing $1 \mu \mathrm{l}$ of both the forward and reverse primers $(10 \mu \mathrm{M})$, $2.5 \mu \mathrm{l}$ of dNTP $(2 \mathrm{mM}), 4 \mu \mathrm{l}$ of magnesium chloride (25 mM), $0.25 \mu$ l of Qiagen DNA polymerase, $5 \mu \mathrm{l}$ of 
'Q-solution' $(5 \times)$, and $2.5 \mu$ of Qiagen buffer $(10 \times)$ (Qiagen Taq PCR Core Kit). Amplification was performed with an initial denaturation for $5 \mathrm{~min}$ at $94^{\circ} \mathrm{C}$, followed by 40 cycles of $1 \mathrm{~min}$ at $94^{\circ} \mathrm{C}, 1 \mathrm{~min}$ at $55^{\circ} \mathrm{C}$ (annealing temperature), and $1 \mathrm{~min}$ at $72^{\circ} \mathrm{C}$ with a final extension of $7 \mathrm{~min}$ at $72^{\circ} \mathrm{C}$. The PCR products were sent to Biomedal Ltd. (Seville, Spain) to be purified and to then undergo 2-direction sequencing. The 815 bp sequences were edited using the Chromas computer software version 2.0, and were manually aligned by the ESEE software version 3.2s (based on Cabot \& Beckenbach 1989) by excluding primer regions. These sequences included a 380 bp fragment that was likely used to define the haplotypes as they are reported in the Archie Carr Center for Sea Turtle Research.

\section{RESULTS}

One sea turtle was admitted to the ARCA del Mar rescue area in 2009 and the other in 2010, both with partially developed external secondary sexual male characteristics. Standard measurements showed that both turtles were juveniles (Wyneken 2001): Animal 1, total body weight $7.2 \mathrm{~kg}$, SCL $34.5 \mathrm{~cm}$, CCL $28 \mathrm{~cm}$, SCW $28 \mathrm{~cm}$, and CCW $33 \mathrm{~cm}$; Animal 2, total body weight $3.62 \mathrm{~kg}$, SCL $27 \mathrm{~cm}$, CCL $30 \mathrm{~cm}$, SCW $22.8 \mathrm{~cm}$, and CCW $28 \mathrm{~cm}$.

Despite the fact that both animals were small and still had sharp keels along the row of vertebral scutes, their tails and claws were larger than those of turtles of similar dimensions. The tail of Animal 1 protruded $15 \mathrm{~cm}$ from the supracaudal scutes of the carapace, and the front claws were slightly curved and 3 times larger $(1.9 \mathrm{~cm}$ long) than those of turtles with a similar body size (Fig. 1). From Animal 2, which was smaller than Animal $1,3 \mathrm{~cm}$ of tail protruded from the supracaudal scutes, and the front claws were twice the size $(1.1 \mathrm{~cm})$ of those of turtles with a similar body size. Average claw length in similar sized turtles accepted into the rehabilitation area was between 0.6 and $0.8 \mathrm{~cm}$ (authors' pers. obs).

During $\mathrm{CO}_{2}$ insufflation of the coelomic cavity prior to coelioscopy, both animals everted the penis out through the cloacal opening, allowing us to note that it was proportionally larger than expected based on the tail size and total animal size. Both penises had the typical anatomical characteristics observed in adult males, including an obvious seminal furrow along the dorsal surface (Fig. 2).

Laparoscopic examination showed that the gonadal tissue clearly corresponded to typical ovarian tissue: the pale pink 'v-shaped' tissue was scalloped at the edges and featured numerous small previtellogenic follicles (Miller \& Limpus 2003, Wyneken et al. 2007). A large, mobile paramesonephric duct close to each gonad was clearly visible in both individuals. As these macroscopic findings indicated female gonads (ovarian tissue) and no testicular tissue were detected, both animals were catalogued as females (Fig. 3).

The female sex for both animals was confirmed histologically by observing a differentiation of the gonadal medulla and the presence of previtellogenic follicles within the stroma. All tissue sam-

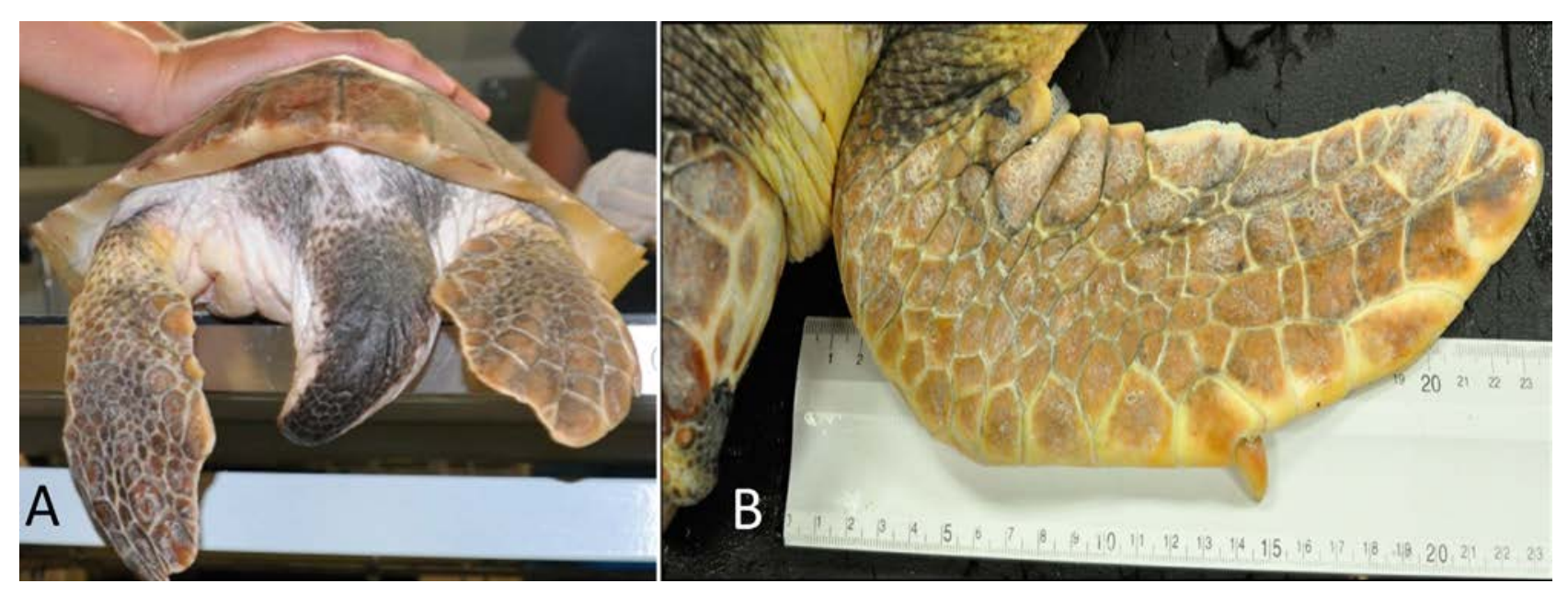

Fig. 1. Caretta caretta. External morphological characteristics of Animal 1. (A) An elongated tail is clearly visible in a caudal view of the animal. (B) The front claws on the front flipper were slightly curved and larger than those of turtles of a similar body size 


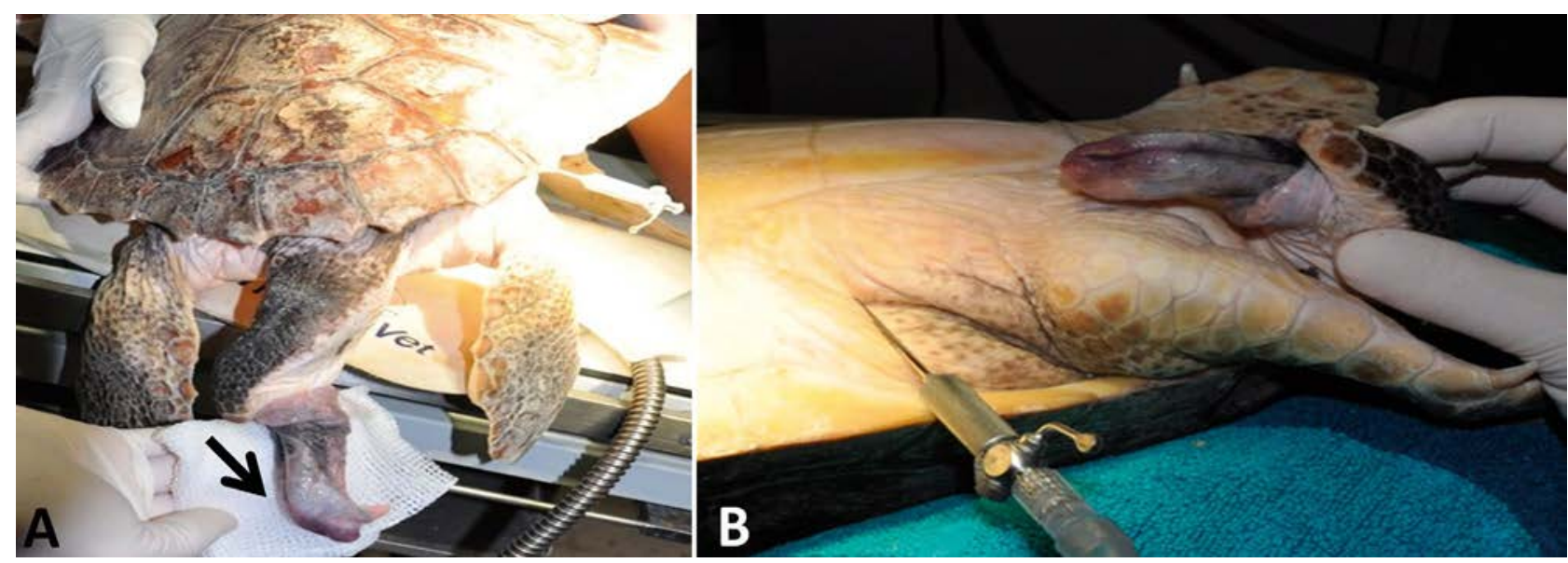

Fig. 2. Caretta caretta. Penile eversion after $\mathrm{CO}_{2}$ insufflation of the coelomic cavity. (A) Animal 1. Global view of penile eversion (arrow) after insufflation. (B) Animal 2. Close-up view of penile eversion

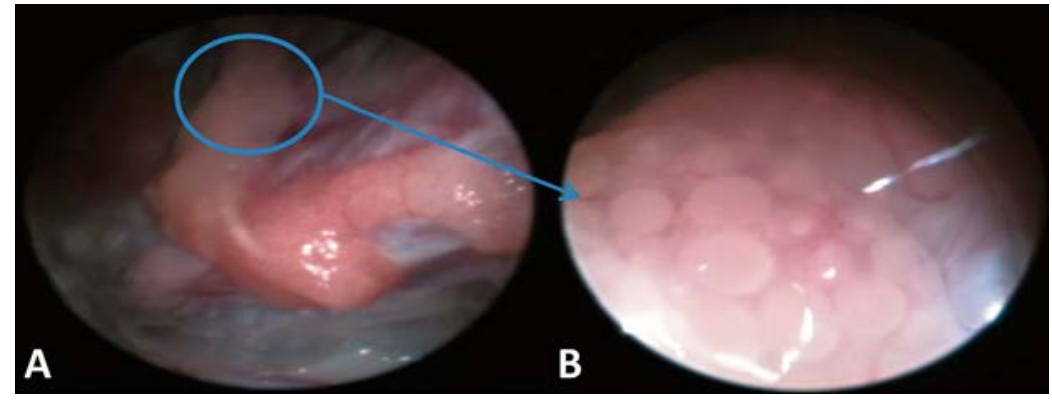

Fig. 3. Caretta caretta. Endoscopic view of Animal 1. (A) Gonad (ovarian tissue). (B) Enlarged view of the same area as in (A), revealing numerous small previtellogenic follicles

ples biopsied from different areas of both gonads in each animal were ovarian, with no signs of testicular tissue (Fig. 4). Consistently with these morphological findings, both animals showed an increase in estrogen levels without variation in testosterone during the stimulation assay, which is the expected response for females (Table 1).

Taken together, our results indicate that Animals 1 and 2 were juvenile loggerhead sea turtles that were developing male sexual secondary features, which were premature based on body size and other external characteristics. In fact, both animals exteriorized an anatomically normal penis during surgery by means of sex identification. Despite these male characteristics, laparoscopic examination, histology, and a hormonal induction assay confirmed both animals to be females, with no evidence of any male gonadal structures.

The sequences obtained for Animals 1 and 2 were blasted in the GenBank resources at NCBI-BLAST,

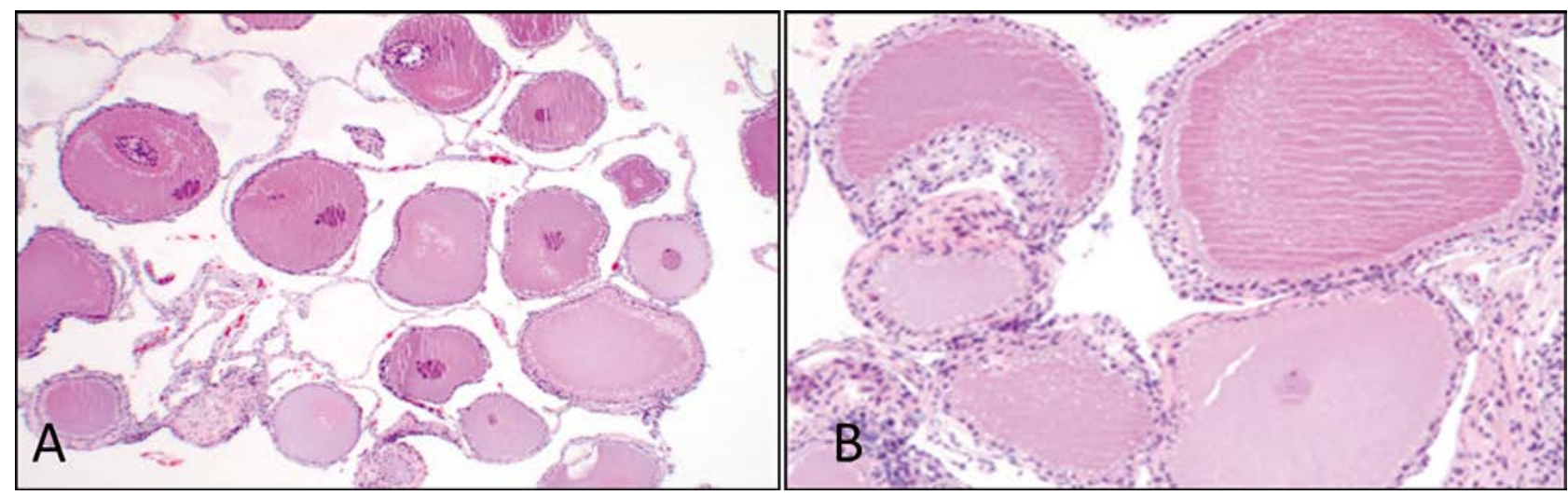

Fig. 4. Caretta caretta. Histological images from biopsied gonads of (A) Animal 1 and (B) Animal 2, showing previtellogenic follicles 
Table 1. Caretta caretta. Hormonal induction assay: hormonal measurements in the plasma of both sea turtles at the baseline time (0) and at 48, 72, 96, and $144 \mathrm{~h}$ after a single injection of intramuscular follicle-stimulating hormone (FSH). A rise in the estradiol plasma concentration (pg ml-1) is clearly visible in both animals as compared with testosterone (ng $\mathrm{ml}^{-1}$ ), which remains at almost the same level after stimulation

\begin{tabular}{|lrrrr|}
\hline $\begin{array}{l}\text { Time (h) } \\
\text { after FSH } \\
\text { injection }\end{array}$ & $\begin{array}{c}\text { Turtle 1 } \\
\text { Estradiol }\end{array}$ & Testosterone & Estradiol & Testosterone \\
\hline 0 & $<10$ & $<0.08$ & $<10$ & 0.2 \\
48 & 18 & 0.08 & 41 & 0.32 \\
72 & 70 & $<0.08$ & 48 & 0.31 \\
96 & $<10$ & $<0.08$ & $<10$ & 0.28 \\
144 & $<10$ & $<0.08$ & $<12$ & 0.36 \\
\hline
\end{tabular}

resulting in a $100 \%$ fit with haplotypes CcA2.1 and CcA3.1, respectively. These sequences were deposited in GenBank under accession numbers KC748470 (Animal 1) and KC748471 (Animal 2).

\section{DISCUSSION}

Our results suggest that both animals are pseudohermaphrodites. All available sex identification techniques were applied to confirm the gender of the animals and to exclude the presence of gonadal tissues of both sexes, which would indicate true hermaphroditism. Laparoscopy was used in combination with a biopsy of the samples taken homogeneously from gonadal tissue. These approaches are the 'gold standard' for gender identification in this species.

These 2 cases of pseudohermaphroditism differ significantly from previous reports of intersex turtles. Those reports described gonads in the form of ovotestes which featured seminiferous tubules in the medulla and previtellogenic follicles in the cortex, and these intersex gonads were stable over time (Limpus et al. 2009). Conversely, however, our 2 cases had only 1 type of immature gonadal tissue (ovary), although they prematurely expressed external masculine characteristics.

The animals in the present study are interesting cases not only because they are female turtles expressing male external characteristics, but also because the male characteristics are precocious. Studies of loggerhead turtles in the Mediterranean region have shown that the average male develops a longer tail when CCL is at least $70 \mathrm{~cm}$ and achieves sexual maturity when CCL is 75 to $80 \mathrm{~cm}$ (Casale et al. 2005). In the present study, CCL was $28 \mathrm{~cm}$ for Animal 1 and $30 \mathrm{~cm}$ for Animal 2.
Hormonal assays examining basal levels of testosterone and estrogen are often used to predict turtle gender (Innis 1997). In some studies, males tested by such assays have shown significantly higher plasma testosterone levels than females (Innis 1997). In addition, these assays seem less reliable when used with young individuals. Given the immaturity of both animals in our study, we opted to perform a hormonal induction assay to detect the presence of the testicular tissue not observed during laparoscopy or multiple biopsies. In this test, levels of testosterone and estrogen are measured following an intramuscular injection of recombinant avian FSH. This assay has been successfully applied in young terrapins and tortoises (Pavgi \& Licht 1990, Innis 1997). In both of our animals, the level of estrogen increased after the injection, but the level of testosterone did not, suggesting not only the presence of ovarian tissue, but also the absence of testicular tissue or of functional male gonadal tissue.

True hermaphroditism usually occurs in association with incubation anomalies, particularly in species displaying TSD as opposed to species in which sex is genetically determined. However, true hermaphroditism should not be manifested as an early expression of secondary sexual characteristics. In some vertebrates, including certain mammals, pseudohermaphroditism can also occur as a result of karyotype defects (Mastromonaco et al. 2012). Since sea turtle sex is not genetically determined, chromosomal errors are unlikely to explain the pseudohermaphroditism of our animals. Reproductive abnormalities often occur in association with exposure to toxic compounds with androgenic effects, otherwise known as EDCs (Webb et al. 2003). EDCs in the environment have been linked to compounds that mimic the effects of estrogens. Reproductive disturbance in aquatic wild males has been reported following exposure to EDCs received from sewage treatment plant (STP) effluents or in rivers contaminated with estrogenic compounds. For years, fish have been considered highly vulnerable to EDCs and have been the subject of interest of many European research programs (Pickering \& Sumpter 2003, Carballo et al. 2005). Other coastal regime species may also be vulnerable to the effect of sea outfalls from STPs, even though contaminated discharges are generally much more diluted in salt waters than in rivers and lakes (Matthiessen 2003). We hypothesize that the most likely cause for these abnormalities is environmental exposure to endocrine disruptors, which presumably led to the defective development of phenotypic sexual characteristics. This explanation seems even 
more likely given the fact that the 2 female turtles expressed masculine characteristics despite being sexually immature.

STP effluents contain natural hormones, such as 17 $\beta$-estradiol (E2) and estrone (E1), which are excreted by women, and estrogenic pharmaceuticals such as ethynylestradiol (EE2), which is widely used for birth control and estrogen replacement therapy (Svenson et al. 2003). In addition, industrial estrogenic chemicals such as phthalates, bisphenol A (BPA), and byproducts of alkyl phenol ethoxylate surfactants, have been extensively detected in wastewater (Pickering \& Sumpter 2003). In Spain, some studies have focused on Catalonia (NE Spain) and have reported the intersex condition in the past (Petrovic et al. 2002). Many persistent environmental pollutants have been reported to cause these effects in aquatic animals. For instance, exposure to many polyaromatic compounds (PCBs, PAHs) or to compounds such as tributyltin has been associated with masculinization in genetically female Japanese flounder Paralichthys olivaceus (Shimasaki et al. 2003). Some areas in the vicinity of industrial and urban locations and in the mouths of the main Mediterranean rivers have been identified as areas of concern due to exposure to persistent organic pollutants (POPs; Gómez-Guttiérez et al. 2007). The presence of androgens and androgen precursors in river water and sediment has been associated with the masculinized phenotype of the female mosquito fish Gambusia holbrooki (Jenkins et al. 2003). POPs in the environment and in eggs also exert endocrine effects on American alligators Alligator mississippiensis (Milnes 2005) and diamondback terrapins Malaclemys terrapin (Basile 2010), and lead to changes in embryonic development.

POPs are abundant across the planet as a result of human activities (Wiig 1998), including several areas of the Mediterranean Sea, where there are many populations of sea turtles (EEA 2005). Sea turtles in Valencian waters derive from both Atlantic and Mediterranean populations, as is the case of the 2 animals in the present study. Numerous studies have documented POPs and metals in sea turtle populations worldwide, mainly based on egg yolk sampling (van de Merwe et al. 2009, Alava et al. 2011, Komoroske et al. 2011, Stewart et al. 2011).

The genetic analysis indicates that both turtles may have hatched in eastern Mediterranean nesting areas (see Garofalo et al. 2009, Piovano et al. 2011, Yilmaz et al. 2012), although one of them may have come from the Atlantic. The mitochondrial haplotype of one of the turtles (CcA3.1) is very common in Turkish rookeries, but is less common in other nesting areas of the Mediterranean and the Atlantic. The most probable origin of this turtle is Turkey. The other turtle presented a mitochondrial haplotype (CcA2.1), which is widely distributed in the Mediterranean and the Atlantic, so it might have hatched anywhere in these areas. In both cases, the turtles might have grown in the western Mediterranean for some years before being transported to the rehabilitation center. Small juveniles from Atlantic rookeries can enter the western Mediterranean as young individuals with very small body sizes, and they can remain in these waters for many years until their body size allows them to return to the Atlantic (Revelles et al. 2007). Small juveniles from Mediterranean rookeries can also arrive in the western Mediterranean following southern European currents along Italian, French, and Spanish coasts. After this journey, they may remain in eastern Spanish feeding grounds for many years (Carreras et al. 2006) until they return to their nesting beaches for breeding.

\section{CONCLUSION}

In this first report of pseudohermaphroditism in Caretta caretta, 2 individuals with premature masculine sexual secondary characteristics were demonstrated to be females. Various lines of evidence suggest endocrine disruptors to be the most likely explanation for these unusual developmental defects. Further research is needed to determine how POPs act as endocrine disruptors in sea turtles. These studies should determine the origin, age, and habitats of affected individuals with a view to considering both the exposure and to quantitate POP levels in the tissues involved in this effect. This work may lead to further studies about the real impact of these contaminants on the environment in general, and on sea turtles in particular.

Our results also suggest the need to reevaluate the suitability of external phenotypical characteristics as the basis for gender identification in sea turtles. Adding laparoscopy to the routine procedures applied in the clinic may help to reveal new cases of pseudohermaphroditism, which will prompt the reassessment of the frequency of this and other sexual disorders in sea turtles. In addition, more research is needed to promote non-invasive techniques of sexing young sea turtles. In this way, improving and developing hormonal assays may prove an important tool for assessing wildlife populations, even when animal size is a real challenge. Furthermore, these techniques can be applied to field and remote conditions. 
Finding out more about the presence of new pseudohermaphroditism cases can help to assess the relevance of these individuals in the population. Firstly, we cannot besure whether they are feasible reproductive animals, despite their hormonal response and gonadal histology apparently being normal. Secondly, this physical impediment assumed present in long-tailed sea turtle females, may complicate, or in the worst cases may prevent, the mating process.

Acknowledgements. We thank all professionals at the Ciudad de las Artes y las Ciencias, especially at the Oceanografic, and also those at Rara Avis Biotec, for their many efforts and complete dedication. In particular, we are grateful to the Conselleria d' Infraestructures, Territori i Medi Ambient of the Valencian Community, who actively participated in the different steps of this study, thereby making it possible. We also thank Karl Storz Iberica, especially S. Marcos del Rincon, for technical and material laparoscopy support. We also thank C. Sánchez Nieto for his assistance in the laboratory work. The genetic part of this work was partially supported by funds from Junta de Andalucía (Plan Andaluz de Investigación Desarrollo e Innovación) to the RNM-108 Research Group.

\section{LITERATURE CITED}

Abreu-Grobois FA, Horrocks J, Formia A, Dutton P and others (2006) New mtDNA Dloop primers which work for a variety of marine turtle species may increase the resolution of mixed stock analyses. In: Frick M, Panagopoulou A, Rees AF, Williams K (comps) Book of abstracts. 26th Annual Symposium on Sea Turtle Biology and Conservation, April 2-8, 2006, Crete. International Sea Turtle Society, Athens, p 179. Available at www.seaturtle society.org/docs/26turtle.pdf

Alava JJ, Keller JM, Wyneken J, Crowder L, Scott G, Kucklick JR (2011) Geographical variation of persistent organic pollutants in eggs of threatened loggerhead sea turtles (Caretta caretta) from southeastern United States. Environ Toxicol Chem 30:1677-1688

Basile ER (2010) Persistent organic pollutants in diamondback terrapin (Malaclemys terrapin) tissues and eggs, and sediments in Barnegat Bay, New Jersey. PhD dissertation, Drexel University, Philadelphia, PA

Broderick AC, Glen F, Godley BJ, Hays GC (2002) Estimating the number of green and loggerhead turtles nesting annually in the Mediterranean. Oryx 36:227-236

Cabot EL, Beckenbach AT (1989) Simultaneous editing of multiple nucleic acid and protein sequences using ESEE. Comput Appl Biosci 5:233-234

Carballo M, Aguayo S, de la Torre A, Muñoz MJ (2005) Plasma vitellogenin levels and gonadal morphology of wild carp (Cyprinus carpio L.) in a receiving rivers downstream of sewage treatment plants. Sci Total Environ 341:71-79

Carreras C, Pont S, Maffucci F, Pascual M and others (2006) Genetic structuring of immature loggerhead sea turtles (Caretta caretta) in the Mediterranean Sea reflects water circulation patterns. Mar Biol 149:1269-1279
Carreras C, Pascual M, Cardona L, Marco A and others (2011) Living together but remaining apart: Atlantic and Mediterranean loggerhead sea turtles (Caretta caretta) in shared feeding grounds. J Hered 102:666-677

Casale P, Laurent L, Gerosa G, Argano R (2002) Molecular evidence of male-biased dispersal in loggerhead turtle juveniles. J Exp Mar Biol Ecol 267:139-145

Casale P, Freggi D, Basso R, Argano R (2005) Size at male maturity, sexing methods and adult sex ratio in loggerhead turtles (Caretta caretta) from Italian waters investigated through tail measurements. Herpetol J 15:145-148

Crews D, Bergeron JM, Bull JJ, Flores D, Tousignant A, Skipper JK, Wibbels T (1994) Temperature-dependent sex determination in reptiles: proximate mechanisms, ultimate outcomes, and practical applications. Dev Genet 15:297-312

Dutton PH, Whitmore CP, Mrosovsky N (1985) Masculinisation of leatherback turtle Dermochelys coriacea hatchlings from eggs incubated in styrofoam boxes. Biol Conserv 31:249-264

EEA (European Environment Agency) (2005) Priority issues in the Mediterranean environment. European Environment Agency Report. EEA, Copenhagen

EPA (Environmental Protection Agency) (2007) Endocrine disruptor screening program (EDSP). Environmental Protection Agency, Washington, DC

Ewert MA, Jackson D, Nelson CE (1994) Patterns of temperature-dependent sex determination in turtles. J Exp Zool 270:3-15

Garofalo L, Mingozzi T, Micò A, Novelletto A (2009) Loggerhead turtle (Caretta caretta) matrilines in the Mediterranean: further evidence of genetic diversity and connectivity. Mar Biol 156:2085-2095

Gómez-Gutiérrez A, Garnacho E, Bayona JM, Albaigés J (2007) Screening ecological risk assessment of persistent organic pollutants in Mediterranean Sea sediments. Environ Int 33:867-876

Hamann M, Godfrey MH, Seminoff JA, Arthur K and others (2010) Global research priorities for sea turtles: informing management and conservation in the 21st century. Endang Species Res 11:245-269

Hernandez-Divers SM, Hernandez-Divers SJ, Wyneken J (2002) Angiographic, anatomic, and clinical technique descriptions of a subcarapacial venipuncture site for chelonians. J Herpetol Med Surg 12:32-37

Innis CJ (1997) Techniques for sexing juvenile chelonians with comments on clinical applicability. In: Proc Association of Reptilian and Amphibian Veterinarians 4th Annual Conference. p 131-133

Janzen FJ, Paukstis GL (1991) Environmental sex determination in reptiles: ecology, evolution, and experimental design. Q Rev Biol 66:149-179

Jenkins RL, Wilson EM, Angus RA, Howell WM, Kirk M (2003) Androstenedione and progesterone in the sediment of a river receiving paper mill effluent. Toxicol Sci 73:53-59

Komoroske LM, Lewison RL, Seminoff JA, Deheyn DD, Dutton PH (2011) Pollutants and the health of green sea turtles resident to an urbanized estuary in San Diego, CA. Chemosphere 84:544-552

Kuchling G (2006) Endoscopic sex determination in juvenile freshwater turtles, Erymnochelys madagascariensis. Chelonian Conserv Biol 5:67-73

Laurent L, Lescure J, Excoffier L, Bowen B and others (1993) Genetic studies of relationship between Mediterranean 
and Atlantic populations of loggerhead turtle (Caretta caretta) with mitochondrial marker. CR Acad Sci III 316: 1233-1239

Limpus CJ, Couper PJ, Read MA (1994) The green turtle, Chelonia mydas, in Queensland: population structure in a warm temperate feeding area. Mem Queensl Mus 35: 139-154

Limpus CJ, Limpus DJ, Read MA, Fitz-Simmons NN (2009) When is a male turtle not a male?-Observations on intersex turtles. Chelonian Conserv Biol 8:102-105

Lutz PL, Musick JA, Wyneken J (2003) The biology of sea turtles. CRC Press, Boca Raton, FL

Mastromonaco GF, Houck ML, Bergfelt DR (2012) Disorders of sexual development in wild and captive exotic animals. Sex Dev 6:84-95

Matthiessen P (2003) Endocrine disruption in marine fish. Pure Appl Chem 75:2249-2261

Miller JD, Limpus CJ (1981) Incubation period and sexual differentiation in the green turtle Chelonia mydas. In: Banks C, Martin A (eds) Proc Melbourne Herpetol Symp Zool Board Victoria, 1981. Zoological Board of Victoria, Parkville, p 66-73

Miller JD, Limpus CJ (2003) Ontogeny of marine turtle gonads. In: Lutz PL, Musick JA, Wyneken J (eds) The biology of sea turtles, Vol II. CRC Press, Boca Raton, FL, p 199-224

Milnes MR (2005) Effects of environmental contaminants on development, sexual differentiation, and steroidogenesis in Alligator mississippiensis. PhD dissertation, University of Florida, Gainesville, FL

Monzón-Argüello C, Rico C, Naro-Maciel E, Varo-Cruz N, López P, Marco A, López-Jurado LF (2010) Population structure and conservation implications for the loggerhead sea turtle of the Cape Verde Islands. Conserv Genet 11:1871-1884

Mrosovsky N, Godfrey MH (1995) Manipulating sex ratios: turtle speed ahead. Chelonian Conserv Biol 1:238-240

Patiño-Martínez J, Marco A, Quiñones L, Hawkes L (2012) A potential tool to mitigate the impacts of climate change to the Caribbean leatherback sea turtle. Glob Change Biol 18:401-411

Pavgi S, Licht P (1990) Steroidal modulation of pituitary gonadotropin-releasing hormone responsiveness in young turtles, Pseudemys scripta. Gen Comp Endocrinol 78:331-343

Petrovic M, Sole M, López de Alda MJ, Barcelo D (2002) Endocrine disruptors in sewage treatment plants, receiving river waters, and sediments: integration of chemical analysis and biological effects on feral carp. Environ Toxicol Chem 21:2146-2156

Pickering AD, Sumpter JP (2003) Comprehending endocrine disruptors in aquatic environments. Environ Sci Technol 17:331A-336A

Pieau C, Mignot TM, Dorizzi M, Guichard A (1982) Gonadal steroid levels in the turtle Emys orbicularis L.: a preliminary study in embryos, hatchlings, and young as a function of the incubation temperature of eggs. Gen Comp Endocrinol 47:392-398

Pieau C, Girondot M, Desvages G, Dorizzi M, RichardMercier N, Zaborski P (1994) Environmental control of gonadal differentiation. In: Short RV, Balaban E (eds) The differences between the sexes. Cambridge University Press, Cambridge, p 433-448

Editorial responsibility: Andrew Cunningham, London, UK
Piovano S, Clusa M, Carreras C, Giacoma C, Pascual M, Cardona L (2011) Different growth rates between loggerhead sea turtles (Caretta caretta) of Mediterranean and Atlantic origin in the Mediterranean Sea. Mar Biol 158: 2577-2587

Raynaud A, Pieau C (1985) Embryonic development of the genital system. In: Gans C, Billett F (eds) Biology of the Reptilia. John Wiley \& Sons, New York, NY, p 149-300

Revelles M, Carreras C, Cardona L, Marco A and others (2007) Evidence for an asymmetric exchange of loggerhead sea turtles between the Mediterranean and the Atlantic through the Straits of Gibraltar. J Exp Mar Biol Ecol 349:261-271

Shimasaki Y, Kitano T, Oshima Y, Inoue S, Imada N, Honjo $\mathrm{T}$ (2003) Tributyltin causes masculinization in fish. Environ Toxicol Chem 22:141-144

Standora EA, Spotila JR (1985) Temperature dependent sex determination in sea turtles. Copeia 1985:711-722

Stewart KR, Keller JM, Templeton R, Kucklick JR, Johnson C (2011) Monitoring persistent organic pollutants in leatherback turtles (Dermochelys coriacea) confirms maternal transfer. Mar Pollut Bull 62:1396-1409

Svenson A, Allard AS, Ek M (2003) Removal of estrogenicity in Swedish municipal sewage treatment plants. Water Res 37:4433-4443

van de Merwe JP, Hodge M, Whittier JM, Lee SY (2009) Analysing persistent organic pollutants in eggs, blood and tissue of the green sea turtle (Chelonia mydas) using gas chromatography with tandem mass spectrometry (GC-MS/MS). Anal Bioanal Chem 393:1719-1731

Venerosi A, Ricceri L, Tait S, Calamandrei G (2012) Sex dimorphic behaviors as markers of neuroendocrine disruption by environmental chemicals: the case of chlorpyrifos. Neurotoxicology 33:1420-1426

Warner DA, Shine R (2011) Interactions among thermal parameters determine offspring sex under temperaturedependent sex determination. Proc R Soc Lond B Biol Sci 278:256-265

Webb S, Taalman R, Becker R, Onuma K, Igarashi K (2003) Risk perception: a chemical industry view of endocrine disruption in wildlife. Pure Appl Chem 75:2575-2591

Whitmore CP, Dutton PH (1985) Infertility, embryonic mortality and nest-site selection in leatherback and green sea turtles in Suriname. Biol Conserv 34:251-272

Wibbels T, Crews D (1995) Steroid-induced sex determination at incubation temperatures producing mixed sex ratios in a turtle with TSD. Gen Comp Endocrinol 100:53-60

Wiig $\varnothing$ (1998) Survival and reproductive rates for polar bears at Svalbard. Ursus 10:25-32

Wyneken J (2001) The anatomy of sea turtles. NOAA Tech Memo NMFS-SEFSC-470. US Department of Commerce, Miami, FL

Wyneken J, Epperly S, Crowder LB, Vaughan J, Blair K (2007) Determining sex in posthatchling loggerhead sea turtles using multiple gonadal and accessory duct characteristics. Herpetologica 63:19-30

Yilmaz C, Turkozan O, Bardakci F, White M, Kararaj E (2012) Loggerhead turtles (Caretta caretta) foraging at Drini Bay in Northern Albania: genetic characterization reveals new haplotypes. Acta Herpetol 7:155-162

Yntema CL, Mrosovsky N (1982) Critical periods and pivotal temperatures for sexual differentiation in loggerhead sea turtles. Can J Zool 60:1012-1016

Submitted: November 19, 2012; Accepted: May 23, 2013

Proofs received from author(s): July 12, 2013 